\title{
Postharvest Life of Cut Chrysanthemum Cultivars in Relation to Chemicals, Wrapping Material and Storage Conditions
}

\author{
Gunjan Sharma and Ranjan Srivastava* \\ Department of Horticulture \\ G.B. Pant University of Agriculture \& Technology \\ Pantnagar-263 145, India
}

\begin{abstract}
A study was conducted to examine the efficacy of chemicals, wrapping material and storage conditions on postharvest life of chrysanthemum cultivars Snowball Yellow and Snowball White. Vase life and flower quality were significantly influenced by chemicals, wrapping material and storage conditions. Minimum weight loss of spikes, maximum total water absorbed, flower diameter and vase life were obtained in treatment $T_{2}$ (4\% sucrose) as compared to control (Tap water). Significant effect of wrapping material and storage condition were also observed on per cent weight loss, total water absorbed maximum flower diameter and vase life in both the cultivars. Wrapping of spikes in PP 200 gauge with refrigerated storage at $3-4{ }^{\circ} \mathrm{C}$ for 3 days +6 hours of simulated transit $\left(T_{3} S_{2}\right)$ resulted in minimum percent weight loss, maximum total water absorbed, flower diameter and maximum vase life in both the cultivars.
\end{abstract}

Keywords: chemicals, chrysanthemum, storage, vase life, wrapping material

\section{INTRODUCTION}

Cut flowers, in general, are highly perishable and chrysanthemums are no exception to it. The high perishability of flowers render them vulnerable to considerable postharvest losses (Bhattacharjee, 1999). In view of market strategy for cut flowers in the country, there are problems of frequent market gluts and price crash. Hence, there is an urgent need to evolve an appropriate packaging and storage technique for cut flowers during periods of decline and also to facilitate long term sea-shipment for export. Postharvest handling involving packaging is imperative to maintain flower freshness and original colour of flower for a longer period which is chiefly governed by internal mechanism that includes balance between water uptake and water loss, stem plugging, respiration rate and production of toxic substances like ethylene and external factors that include environmental conditions and microbial attack on the cut ends. The vase life of cut flowers is influenced by variety of factors like climate, variety, harvesting time, postharvest handling etc. (Bhattacharjee, 1999). A wide range of floral preservatives in the form of germicides, ethylene antagonistics and source of energy (sucrose) are in use to preserve flower quality and extending Postharvest longevity of cut flowers. Postharvest management and value addition can increase prices of cut flowers up to 9-10 times. A variety of preservatives and temperature treatments have been advocated for extending the vase life of cut flowers of different varieties. However, such information on crop varieties growing under Tarai conditions is scanty. Therefore, the

\footnotetext{
*Corresponding author: ranjansrivastava25@gmail.com
} 
present investigation was undertaken to study the influence of chemicals, wrapping material and storage conditions on postharvest life of chrysanthemum under 'Tarai' conditions.

\section{MATERIALS AND METHODS}

The present investigation was carried out at Model Floriculture Centre of the University located at $29^{\circ} \mathrm{N}$ latitude, $79.3^{\circ} \mathrm{E}$ longitude in the Tarai belt of Himalayas. The experimental materials consist of chrysanthemum varieties Snowball Yellow $\left(\mathrm{V}_{1}\right)$ and Snowball White $\left(\mathrm{V}_{2}\right)$. The crop was raised under naturally ventilated poly house with uniform standard cultural practices. The stems were harvested with the help of sharp secateurs at 8:00 am in the morning when 50 per cent of flowers were about $34^{\text {th }}$ open in field. Stem length of all flowers were uniformly maintained i.e. $25 \mathrm{~cm}$. Chemical preservatives used in the present study comprised of sucrose ( 2 and 4\%), citric acid (100 and $200 \mathrm{ppm}$ ) and 8-HQC (150 and 200 ppm). Sucrose, a carbohydrate, was used as a carbon source of energy while citric acid and 8-HQC were used for their anti-bacterial properties. Cut stems were kept in different holding solutions, $\mathrm{T}_{0}$ - Tap water (Control), $\mathrm{T}_{1}$ - Sucrose (2\%), $\mathrm{T}_{2}$ - Sucrose (4\%), $\mathrm{T}_{3}$ - Citric acid $(100 \mathrm{ppm}), \mathrm{T}_{4}-$ Citric acid (200 ppm), $\mathrm{T}_{5}-8$-HQC (150 ppm), $\mathrm{T}_{6}-8$-HQC (200 ppm). Wrapping materials consists of $\mathrm{T}_{1}$ - LDPE 100 gauge, $\mathrm{T}_{2}$ - PP 100 gauge, $\mathrm{T}_{3}$ - PP 200 gauge, $\mathrm{T}_{4}$ - Cellophane, $\mathrm{T}_{5}$ - Newspaper, $\mathrm{T}_{6}-$ Brown paper, $\mathrm{T}_{7}-$ Open (Control) with storage conditions $\mathrm{S}_{1}$ - Normal storage conditions $\left(25{ }^{\circ} \mathrm{C}\right.$ Temp. $), \mathrm{S}_{2}-$ Storage under refrigerated conditions $\left(3-4{ }^{\circ} \mathrm{C}\right)+6$ hours of simulated transit, $S_{3}$ - Storage under refrigerated conditions $\left(3-4{ }^{\circ} \mathrm{C}\right)+16$ hours of simulated transit till the completion of the experiment. The experiment was laid out in 2- factorial CRD with three replications. Observations like vase life, flower diameter, per cent weight loss and maximum water absorbed were then recorded/ calculated.

\section{RESULTS AND DISCUSSION}

Postharvest characteristics of chrysanthemum cultivars were significantly affected by different chemical treatments, wrapping materials, storage conditions as well as varieties and their interaction. Minimum per cent weight loss, maximum flower diameter and maximum vase life of flowers were observed in the stems treated with sucrose $4 \%\left(\mathrm{~T}_{2}\right)$ (Table 1). $\mathrm{T}_{2}$ recorded minimum per cent weight loss $(33.12 \%)$ and it was found to be statistically at par with stems pulsed with sucrose $(2 \%)\left(\mathrm{T}_{1}\right)$ wherein per cent weight loss of $35.84 \%$ was recorded and the maximum weight loss $(47.35 \%)$ was recorded in $\mathrm{T}_{0}$. Data further revealed that barring different solutions, variety did not have any significant effect on per cent weight loss. As far as interaction is concerned, $\mathrm{T}_{2} \mathrm{~V}_{1}$ recorded minimum $(31.36 \%)$ per cent weight loss which was found to be statistically at par with $T_{1} V_{2}$ as well as $T_{1} V_{1}$ in which per cent weight losses of $35.42 \%$ and $36.26 \%$ were recorded, respectively whereas it was maximum (48.94\%) in $\mathrm{T}_{0} \mathrm{~V}_{2}$. Minimum per cent weight loss can be attributed to better water conductance through stem due to sucrose which was also utilized as the source of energy by cut flower stem and in other treatments, the germicidal properties of 8-HQC in addition to ethylene inhibition, might have helped in higher uptake of water by the flowers, resulting in gain in fresh weight. Results obtained are also in close proximity with the findings of Park et al. (2000) who recorded higher fresh weight of cut chrysanthemum spikes kept in a solution 
Table1. Effect of different holding solutions on per cent weight loss, flower diameter and vase life in cut chrysanthemum cultivars, Snowball Yellow $\left(V_{1}\right)$ and Snowball White $\left(\mathbf{V}_{2}\right)$

\begin{tabular}{|c|c|c|c|c|c|c|c|c|c|}
\hline \multirow[t]{2}{*}{ Treatments } & \multicolumn{3}{|c|}{ Per cent weight loss $(\%)$} & \multirow{2}{*}{$\begin{array}{c}\text { Flower } \\
(\mathbf{c m}) \\
V_{1}\end{array}$} & \multicolumn{2}{|c|}{ diameter } & \multicolumn{3}{|c|}{ Vase life (days) } \\
\hline & $V_{1}$ & $\mathbf{V}_{2}$ & Mean & & $\mathbf{V}_{2}$ & Mean & $\mathbf{V}_{1}$ & $\mathbf{V}_{2}$ & Mean \\
\hline $\mathrm{T}_{0}:$ (Tap water) & 45.76 & 48.94 & 47.35 & 7.03 & 8.06 & 7.55 & 20.00 & 18.33 & 19.16 \\
\hline $\mathrm{T}_{1}:(2 \%$ sucrose $)$ & 36.26 & 35.42 & 35.84 & 7.63 & 8.63 & 8.13 & 26.33 & 24.66 & 25.50 \\
\hline $\mathrm{T}_{2}:(4 \%$ sucrose $)$ & 31.36 & 34.88 & 33.12 & 7.86 & 8.80 & 8.33 & 27.33 & 26.33 & 26.83 \\
\hline $\mathrm{T}_{3}:(100 \mathrm{ppm}$ citric acid $)$ & 43.31 & 43.93 & 43.62 & 7.16 & 8.23 & 7.69 & 21.66 & 20.66 & 21.16 \\
\hline $\mathrm{T}_{4}:(200 \mathrm{ppm}$ citric acid $)$ & 42.48 & 39.87 & 41.17 & 7.33 & 8.33 & 7.83 & 23.33 & 21.66 & 22.50 \\
\hline $\mathrm{T}_{5}:(150 \mathrm{ppm} 8-\mathrm{HQC})$ & 38.72 & 39.73 & 39.22 & 7.46 & 8.40 & 7.93 & 24.33 & 22.66 & 23.50 \\
\hline $\mathrm{T}_{6}:(200 \mathrm{ppm} 8-\mathrm{HQC})$ & 36.71 & 37.45 & 37.08 & 7.53 & 8.53 & 8.03 & 24.66 & 24.00 & 24.33 \\
\hline \multirow[t]{2}{*}{ Mean } & 39.23 & 40.03 & 39.63 & 7.43 & 8.42 & 7.93 & 23.95 & 22.61 & 23.28 \\
\hline & S.Em \pm & \multicolumn{2}{|c|}{$\mathrm{CD}$ at $5 \%$} & S.Em \pm & \multicolumn{2}{|c|}{$\mathrm{CD}$ at $5 \%$} & S.Em \pm & \multicolumn{2}{|c|}{$\mathrm{CD}$ at $5 \%$} \\
\hline Varieties (V) & 0.64 & \multicolumn{2}{|c|}{1.87} & 0.30 & \multicolumn{2}{|c|}{0.89} & 0.13 & \multicolumn{2}{|c|}{0.37} \\
\hline Treatments $(\mathrm{T})$ & 1.20 & \multicolumn{2}{|c|}{3.49} & 0.57 & \multicolumn{2}{|c|}{0.16} & 0.24 & \multicolumn{2}{|c|}{0.70} \\
\hline Interaction $(\mathrm{V} * \mathrm{~T})$ & 1.70 & \multicolumn{2}{|c|}{4.94} & 0.81 & \multicolumn{2}{|c|}{0.23} & 0.34 & \multicolumn{2}{|c|}{1.99} \\
\hline
\end{tabular}

containing $\mathrm{Al}_{2}\left(\mathrm{SO}_{4}\right)_{3}(250 \mathrm{ppm})$ and sucrose (3\%). Among the different holding solutions, the larger flower diameter was observed in treatment $\mathrm{T}_{2}$ (sucrose $4 \%$ ). Irrespective of treatments, variety $\left(\mathrm{V}_{2}\right)$ recorded maximum average flower diameter $(8.42 \mathrm{~cm})$ which was significantly higher than the average maximum diameter recorded in variety $\left(\mathrm{V}_{1}\right)(7.43 \mathrm{~cm})$. In both the varieties, maximum flower diameter increased significantly over control in all the chemical treatments. Interaction data show that $\mathrm{T}_{2} \mathrm{~V}_{2}$ produced maximum flower diameter $(8.80 \mathrm{~cm})$ while interaction $\mathrm{T}_{0} \mathrm{~V}_{1}$ recorded minimum flower diameter $(7.03 \mathrm{~cm})$ attained in vase. Possible explanation for gain in flower diameter may be the maintenance of higher fresh weight by maximum water uptake as a result of avoidance of blockage of xylem tissues by 8-HQC and utilization of sucrose as source of energy by the cut flower stem. Moreover, the accumulation of carbohydrates and water uptake would have had direct effect on increase in the cell volume. Besides, sucrose availability might have facilitated higher rate of respiration necessary for cell division, cell enlargement and providing ' $\mathrm{C}$ ' skeleton for the tissue structure contributing to flower expansion and formation of cell constituents and thus caused increase in petal size as observed by Ho and Nicholes (1977) in rose corollas. All holding solutions significantly increased the vase life which ranged from 20.00 to 23.77 days and 18.33 to 36.33 days in different vase solutions in cultivars $\mathrm{V}_{1}$ and $\mathrm{V}_{2}$, respectively. However, when compared with all other chemical treatments, sucrose $(4 \%)\left(\mathrm{T}_{2}\right)$ recorded maximum vase life (26.83 days). Higher average vase life of 23.95 days was observed in $\mathrm{V}_{1}$ and interaction $\mathrm{T}_{2} \mathrm{~V}_{1}$ recorded maximum vase life of 27.33 days. The enhanced longevity of sucrose pulsed stems could be attributed to continued and increased water uptake in the stems, cellular turgidity, enhanced fresh weight and dry weight, better petal size and optimum continuation of cell metabolism, specially respiration that facilitated cell growth and development, formation of cellular constituents and liberation of energy for other cellular function. While, the shortest vase life of flowers kept in distilled water could be correlated with decreased water uptake in cut stems due to microbes which stimulated the formation of vascular occlusions in the stem as advocated by Lineberger and Stepkonus (1976). Average per cent weight loss, flower diameter and vase life was also significantly influenced by wrapping material and storage conditions in both the chrysanthemum cultivars. Among all the treatments used, stems wrapped in PP 200 gauge $\left(\mathrm{T}_{3}\right)$ resulted in minimum postharvest percent weight loss $(39.02 \%)$ in variety 'Snowball Yellow'(Table 2) and (42.04\%) in variety 'Snowball White'(Table 3). Stems stored in refrigerated condition $\left(3-4{ }^{\circ} \mathrm{C}\right)$ for 3 days and subjected to $6 \mathrm{hr}$ simulated transit $\left(\mathrm{S}_{2}\right)$ depicted minimum per cent weight loss in both the cultivars. Among the interactions, stems wrapped in PP 200 gauge and stored under 
refrigerated conditions $\left(3-4^{\circ} \mathrm{C}\right)$ for 3 days and subjected to $6 \mathrm{hr}$ simulated transit $\left(\mathrm{T}_{3} \mathrm{~S}_{2}\right)$ was found to be the best in reducing the per cent weight loss in both the chrysanthemum cultivars. This may be due to the water loss which accounts for per cent physiological loss in weight which was less when cut flowers were stored at lower temperature. Moreover, low cold storage temperature slows down transpirational loss of water and respirational loss of carbohydrates which reduces the loss of weight during storage. The results are in conformity with the findings of Hardenburg et al. (1990) and Beura and Singh (2003). Similarly, both flower diameter and vase life were found to be maximum in treatment $\mathrm{T}_{3}$ when stored under refrigerated conditions $\left(3-4{ }^{\circ} \mathrm{C}\right)$ for 3 days and subjected to $6 \mathrm{hr}$ in both Snowball Yellow and Snowball White (Table 2,3). The interaction effect was found to be significant and maximum flower diameter attained $(7.76 \mathrm{~cm})$ in 'Snowball Yellow' and $(8.56 \mathrm{~cm})$ 'Snowball White' was reported in stems wrapped in PP 200 gauge and stored under refrigerated condition $\left(3-4{ }^{\circ} \mathrm{C}\right)$ for 3 days $+6 \mathrm{hr}$ simulated transit $\left(\mathrm{T}_{3} \mathrm{~S}_{2}\right)$. This may be due to the fact that the flowers wrapped in polypropylene had higher moisture retention and further storing them at low temperature resulted in lower metabolic activities like respiration, transpiration and maintained high humidity which resulted in easy and more flower opening. Moreover, the beneficial effect of low temperature storage was due to the fact that it not only affects metabolic and physical activities of petal damage and shrinking. Similar findings were reported by Nowak and Rudnicki (1984) and Singh et al. (2007) in gladiolus.

\section{CONCLUSION}

It can be concluded that sucrose (4\%) is effective in improving postharvest quality of cut chrysanthemum varieties. Wrapping of cut chrysanthemum spikes with PP 200 gauge and storing them under refrigerated conditions at $3-4^{0} \mathrm{C}$ for 3 days and $6 \mathrm{hrs}$ of simulated transit markedly conserved flower quality and longevity.

\section{REFERENCES}

Beura, S. and Singh, R. (2003). Effect of storage temperature and wrapping material on postharvest life of gladiolus cultivar Her Majesty. J. Orna. Hort., 6(4). 322 - 327.

Bhattacharjee, S.K. (1999). Postharvest management of cut flowers, cut foliage and postharvest management of potted plant. J. Orna. Hort. New Series, 2(1), 32 - 39.

Hardenburg, R.E., Watada, A.E. and Wang, C.Y. (1990). The commercial storage of fruits, vegetables and florist and nursery stocks. USDA Agri. Handbook, 66: 130.

Ho, L.C. and Nicholas, R. (1977). Translocation of 14 C-sucrose in relation to changes in carbohydrate content in rose corollas cut at different stages of development. Ann. Bot., 41, $227-242$.

Lineberger, R.D. and Steponkus, P.L. (1976). Identification and localization of vascular occlusions in cut roses. J. Amer. Hort. Sci., 94, 223 - 226.

Nowak, J and Rudnicki, R.M. (1984). Cold storage of gladiolus cut spikes. Prace-InstytutuSadownictwa-i-kwiacfarstwa-w-Skterniewicach-Rosliny-Ozdobne, 9, 67 - 72. 
Park, Y.Y., Kim, H.K. and Cho, M.S. (2000). Effect of sucrose germicides and ABA in preservatives on postharvest quality of cut chrysanthemum 'kyoungsubang'. Korean J. Life Sci., 10(6), 591 - 597.

Singh, A., Kumar, J. and Kumar, P. (2007). Effect of different packaging films and cold storage durations on keeping quality of gladiolus cut spikes. J. Orna. Hort., 10(4), 235 - 239 
Table 2. Effect of different storage conditions and wrapping materials on postharvest characteristics of cut chrysanthemum cultivar Snowball Yellow

\begin{tabular}{|c|c|c|c|c|c|c|c|c|c|c|c|c|}
\hline \multicolumn{13}{|l|}{ Treatments } \\
\hline (Wrapping material) & \multicolumn{4}{|c|}{ Per cent weight loss $(\%)$} & \multicolumn{4}{|c|}{ Flower diameter $(\mathrm{cm})$} & \multicolumn{4}{|c|}{ Vase life (days) } \\
\hline & $\mathrm{S}_{1}$ & $\mathrm{~S}_{2}$ & $\mathrm{~S}_{3}$ & Mean & $\mathrm{S}_{1}$ & $\mathrm{~S}_{2}$ & $\mathrm{~S}_{3}$ & Mean & $\mathrm{S}_{1}$ & $\mathrm{~S}_{2}$ & $\mathrm{~S}_{3}$ & Mean \\
\hline $\mathrm{T}_{1}$ : (LDPE 100 gauge) & 42.15 & 39.14 & 43.71 & 41.66 & 7.19 & 7.30 & 7.03 & 7.17 & 17.00 & 20 & 15.33 & 17.44 \\
\hline $\mathrm{T}_{2}:(\mathrm{PP} 100$ gauge $)$ & 39.13 & 37.52 & 42.18 & 39.61 & 7.50 & 7.56 & 7.40 & 7.48 & 17.33 & 20.66 & 16.33 & 18.11 \\
\hline $\mathrm{T}_{3}:(\mathrm{PP} 200$ gauge $)$ & 38.58 & 36.56 & 41.93 & 39.02 & 7.63 & 7.76 & 7.46 & 7.62 & 18.66 & 21.66 & 17.33 & 19.22 \\
\hline $\mathrm{T}_{4}:($ Cellophane $)$ & 43.01 & 41.5 & 44.79 & 43.10 & 7.33 & 7.46 & 7.23 & 7.34 & 18.33 & 21.33 & 16.66 & 18.77 \\
\hline $\mathrm{T}_{5}:$ (Newspaper) & 44.39 & 42.91 & 46.47 & 44.59 & 6.83 & 7.20 & 6.80 & 6.94 & 16.33 & 19.66 & 14.66 & 16.88 \\
\hline $\mathrm{T}_{6}:($ Brown paper $)$ & 43.93 & 42.11 & 45.90 & 43.98 & 6.70 & 7.13 & 6.63 & 6.82 & 15.33 & 19.33 & 14.00 & 16.22 \\
\hline $\mathrm{T}_{7}:$ Open (Control) & 46.16 & 45.01 & 47.87 & 46.35 & 6.46 & 6.96 & 6.33 & 6.58 & 14.66 & 17.66 & 13.33 & 15.22 \\
\hline \multirow[t]{2}{*}{ Mean } & 42.48 & 40.68 & 44.69 & 42.62 & 7.09 & 7.34 & 6.98 & 7.14 & 16.80 & 20.04 & 15.38 & 17.41 \\
\hline & S.Em \pm & \multicolumn{3}{|c|}{$\mathrm{CD}$ at $5 \%$} & \multicolumn{2}{|c|}{ S.Em \pm} & \multicolumn{2}{|c|}{$\mathrm{CD}$ at $5 \%$} & S.Em \pm & \multicolumn{3}{|c|}{ CD at $5 \%$} \\
\hline Storage condition $(\mathrm{S})$ & 0.59 & \multicolumn{3}{|c|}{1.70} & \multicolumn{2}{|c|}{0.46} & \multicolumn{2}{|c|}{0.13} & 0.19 & \multicolumn{3}{|c|}{0.54} \\
\hline Wrapping material (T) & 0.91 & \multicolumn{3}{|c|}{2.60} & \multicolumn{2}{|c|}{0.74} & \multicolumn{2}{|c|}{0.20} & 0.29 & \multicolumn{3}{|c|}{0.83} \\
\hline Interaction $(\mathrm{S} * \mathrm{~T})$ & 1.58 & \multicolumn{3}{|c|}{4.52} & \multicolumn{2}{|c|}{0.12} & \multicolumn{2}{|c|}{0.34} & 0.50 & \multicolumn{3}{|c|}{1.43} \\
\hline
\end{tabular}

Table 3. Effect of different storage conditions and wrapping materials on Postharvest characteristics of cut chrysanthemum cultivar Snowball White 


\begin{tabular}{|c|c|c|c|c|c|c|c|c|c|c|c|c|c|}
\hline \multicolumn{14}{|l|}{ Treatments } \\
\hline (Wrapping material) & \multicolumn{4}{|c|}{ Per cent weight loss $(\%)$} & \multicolumn{4}{|c|}{ Flower diameter $(\mathrm{cm})$} & & \multicolumn{4}{|c|}{ Vase life (days) } \\
\hline & $\mathrm{S}_{1}$ & $\mathrm{~S}_{2}$ & $\mathrm{~S}_{3}$ & Mean & $\mathrm{S}_{1}$ & $\mathrm{~S}_{2}$ & $\mathrm{~S}_{3}$ & Mean & & $\mathrm{S}_{1}$ & $\mathrm{~S}_{2}$ & $\mathrm{~S}_{3}$ & Mean \\
\hline $\mathrm{T}_{1}:(\mathrm{LDPE} 100$ gauge $)$ & 45.12 & 44.11 & 45.82 & 45.01 & 8.00 & 8.10 & 7.83 & 7.97 & & 16.33 & 19.33 & 13.00 & 16.22 \\
\hline $\mathrm{T}_{2}:(\mathrm{PP} 100$ gauge $)$ & 44.42 & 43.13 & 44.69 & 44.08 & 8.30 & 8.36 & 8.20 & 8.28 & & 16.66 & 20.33 & 13.66 & 16.88 \\
\hline $\mathrm{T}_{3}:(\mathrm{PP} 200$ gauge $)$ & 41.87 & 40.44 & 43.80 & 42.04 & 8.43 & 8.56 & 8.26 & 8.42 & & 18.33 & 21.33 & 15.33 & 18.33 \\
\hline $\mathrm{T}_{4}:($ Cellophane $)$ & 45.85 & 44.45 & 46.56 & 45.62 & 8.13 & 8.26 & 8.03 & 8.14 & & 17.66 & 20.66 & 14.66 & 17.66 \\
\hline $\mathrm{T}_{5}:$ (Newspaper) & 47.07 & 47.46 & 49.09 & 47.87 & 7.63 & 8.00 & 7.60 & 7.74 & & 15.66 & 17.33 & 12.00 & 14.66 \\
\hline $\mathrm{T}_{7}:$ Open (Control) & 49.79 & 48.01 & 51.97 & 49.92 & 7.26 & 7.76 & 7.13 & 7.38 & & 13.66 & 16.33 & 11.66 & 13.88 \\
\hline \multirow[t]{2}{*}{ Mean } & 45.80 & 44.84 & 47.10 & 45.91 & 7.90 & 8.14 & 7.78 & 7.94 & & 16.14 & 19.00 & 13.28 & 16.14 \\
\hline & \multicolumn{2}{|c|}{ S.Em \pm} & \multicolumn{2}{|c|}{$\mathrm{CD}$ at $5 \%$} & \multicolumn{4}{|c|}{ S.Em \pm} & $\mathrm{CD}$ at $5 \%$ & S.Em \pm & \multicolumn{3}{|c|}{$\mathrm{CD}$ at $5 \%$} \\
\hline Storage condition (S) & \multicolumn{2}{|c|}{0.57} & \multicolumn{2}{|c|}{1.65} & \multicolumn{4}{|c|}{0.45} & 0.13 & 0.21 & \multicolumn{3}{|c|}{0.61} \\
\hline Wrapping material $(\mathrm{T})$ & \multirow{2}{*}{\multicolumn{2}{|c|}{$\begin{array}{l}0.88 \\
1.53\end{array}$}} & \multicolumn{2}{|c|}{2.52} & \multicolumn{4}{|c|}{0.70} & 0.20 & 0.32 & \multicolumn{3}{|c|}{0.93} \\
\hline Interaction $(\mathrm{S} * \mathrm{~T})$ & & & \multicolumn{2}{|c|}{4.37} & \multicolumn{4}{|c|}{0.12} & 0.349 & 0.56 & \multicolumn{3}{|l|}{1.62} \\
\hline
\end{tabular}

$\mathbf{S}_{1}$ : Normal storage conditions $\left(25^{\circ} \mathrm{C}\right.$ Temp. $) ; \mathbf{S}_{2}:$ Storage under refrigerated conditions $\left(3-4^{\circ} \mathrm{C}\right)+6$ hours of simulated transit $\mathbf{S}_{3}:$ Storage under refrigerated conditions $\left(3-4^{\circ} \mathrm{C}\right)+6$ hours of simulated transit 